\title{
Clinicopathological and biological significance of CDC28 protein kinase regulatory subunit 2 overexpression in human gastric cancer
}

\author{
FUMIAKI TANAKA $^{1 *}$, SHINJI MATSUZAKI ${ }^{1,2^{*}}$, KOSHI MIMORI $^{1}$, \\ YOSHIAKI KITA $^{1,3}$, HIROSHI INOUE ${ }^{1}$ and MASAKI MORI ${ }^{1,4}$
}

\begin{abstract}
${ }^{1}$ Department of Molecular and Surgical Oncology, Medical Institute of Bioregulation, Kyushu University, 4546 Tsurumihara, Beppu 874-0838; ${ }^{2}$ Faculty of Medicine, Toyama University, 2630 Sugitani, Toyama 930-0194;

${ }^{3}$ Department of Surgical Oncology and Digestive Surgery, Graduate School of Medical and Dental Science, Kagoshima University, 8-35-1 Sakuragaoka, Kagoshima 890-8520; ${ }^{4}$ Department of Gastroenterological Surgery, Graduate School of Medicine, Osaka University, 2-2 Yamadaoka, Suita 565-0871, Japan
\end{abstract}

Received February 4, 2011; Accepted March 23, 2011

DOI: $10.3892 /$ ijo.2011.1056

\begin{abstract}
CDC28 protein kinase regulatory subunit 2 (CKS2) is a cyclin-dependent kinase subunit (CKS) family member that participates in cell cycle regulation. Few studies have investigated its involvement in gastric cancer. In this study, we focused on the clinical and biological significance of $C K S 2$ overexpression in gastric cancer. The expression of CKS 2 mRNA was studied by real-time quantitative reverse transcription polymerase chain reaction, and the expression status in each tumor was examined to varify whether any correlation existed with clinical and pathological factors. In addition, an immunohistochemical study was performed in selected samples. Moreover, we examined the impact of $C K S 2$-siRNA in a gastric cancer cell line. A significantly higher expression of $C K S 2$ mRNA was found in tumor tissues compared to paired normal tissues $(\mathrm{p}<0.01)$. Immunohistochemical analyses led to similar results. The overall five-year survival rate was significantly higher in the low $C K S 2$ expression group (59.9\%) than in the high $C K S 2$ expression group $(23.9 \%)(\mathrm{p}<0.01)$. Univariate and multivariate analysis showed that $C K S 2$ expression status was an independent prognostic factor (relative risk, $1.41 ; 95 \%$ confidence interval, 1.01-1.97; $\mathrm{p}<0.05$ ). Moreover, the inhibition of cellular proliferation by $C K S 2$-siRNA was observed in a gastric cancer cell line. $C K S 2$ is one of the gastric cancer-
\end{abstract}

Correspondence to: Professor Masaki Mori, Department of Gastroenterological Surgery, Graduate School of Medicine, Osaka University, 2-2 Yamadaoka, Suita 565-0871, Japan

E-mail: mmori@gesurg.med.osaka-u.ac.jp

*Contributed equally

Key words: CDC28 binding protein regulatory subunit 2, gastric cancer, prognosis, apoptosis related genes that correlates with biological aggressiveness and poor prognosis of gastric cancer. Thus, $C K S 2$ is a possible candidate gene for diagnosis, as well as targeted molecular diagnosis and therapy in gastric cancer.

\section{Introduction}

Cell cycle phase transitions are regulated by cyclin-dependent protein kinases (cdks) and their cyclin binding partners. Cell cycle regulatory failure is associated with the development or the progression of cancer (1-5). Cyclin-dependent kinase subunit (CKS) proteins play a role in mitosis, and they bind to and regulate the activity of the cdks $(6,7)$. In mammals, there are two homologs, $C K S 1$ and $C K S 2$ (8). Both $C K S 1$ and $C K S 2$ consist of 79 amino acids, and show $81 \%$ homology. $C K S 1$ is a specific co-factor that is necessary for the degradation and ubiquitination of p27 by $\mathrm{SCF}^{\mathrm{Skp} 2}$. Human CKS1 binds to Skp2 and increases the binding of threonine 187-phosphorylated p27 to Skp2 $(9,10)$. However, $C K S 2$ has been termed $C D C 28$ protein kinase regulatory subunit 2 , as it binds to the catalytic subunit of cdk. CKS2 activates the CDC2-cyclin B complex that binds to a part of cdk and controls cell cycle transitions (11).

Gastric cancer is one of the most aggressive forms of cancer of the gastrointestinal tract and it is lethal when it is not diagnosed at an early stage. A high incidence of gastric cancer has persisted in Japan, South America and Eastern European countries. According to surveillance, epidemiology, and end results (SEER) data, an estimated 21,500 new cases of gastric cancer were diagnosed in the United States in 2008, and an estimated 10,880 patients will died of gastric cancer in spite of improvements in surgery and chemotherapy (12). In Japan, it is the second most frequent form of cancer and approximately 50,000 people die of the disease annually (13-15). To improve the survival rates from gastric cancer, the development of new treatments is crucial.

Molecular events resulting in the progression of gastric cancer are complex and poorly understood. However, some 
gastric cancer risk factors have been identified, such as Helicobacter pylori infection and genetic alterations $(16,17)$. Furthermore, the discovery of novel molecular markers has facilitated the understanding of the molecular and cellular mechanisms underlying the development and progression of gastric cancer (18). It would be beneficial to identify novel gastric cancer molecular markers that could help both early diagnosis and treatment of the disease. We have previously shown that CKS1 is a predictive marker for the prognosis of gastric cancer patients (19). However, there are few studies on the clinical significance of $C K S 2$ in human gastric cancer. In this study, we investigated $C K S 2$ expression in 109 gastric cancer patients and analyzed its clinical significance.

\section{Material and methods}

Cell lines and RNA human tissues. The human gastric cancer cell lines, KATOIII, MKN1, MKN7, MKN28, MKN45, MKN74, NUGC3 and NUGC4 were provided by the Japanese Cancer Research Bank, Tokyo, Japan. Cell lines were maintained in RPMI-1640 medium (Invitrogen Corp., CA, USA) supplemented with $10 \%$ fetal bovine serum (FBS) (Equitec-Bio Inc., TX, USA), 100 units $/ \mathrm{ml}$ penicillin $\mathrm{G}$ and streptomycin (Invitrogen Corp.). The cells were incubated in $5 \% \mathrm{CO}_{2}$ at $37^{\circ} \mathrm{C}$ and passaged every three to four days (MKN7, at seven day intervals). For normal human tissue RNA, we used human universal reference total RNA (Clontech Laboratories, Inc., CA, USA).

Subjects and clinical samples. Subjects consisted of 109 patients with gastric cancer who underwent surgery at the Division of Surgical Oncology, Kyushu University Hospital (Beppu, Japan) and affiliated hospitals between 1989 and 2000. The median age of the patients was 65.9 years (range, 36-87 years). The distribution of genders was 74 males and 35 females. All patients underwent resection of the primary tumor. None of these patients had received pre-operative chemotherapy or radiotherapy prior. Written informed consent was obtained from all patients. The longest follow-up period was 11.2 years. Every patient was definitively identified as having gastric cancer based on the clinicopathological findings. Among 109 cases of gastric cancer entered in this study, 49 cases had post-operative chemotherapy ( $5 \mathrm{FU}$ for 42 cases and other drugs for seven cases), 48 did not, and the remaining 12 cases were unknown. Clinicopathological factors were assessed according to the criteria of the Japanese Classification of Gastric Carcinoma (20). The tumor and paired normal tissue samples were immediately frozen in liquid nitrogen and kept at $-80^{\circ} \mathrm{C}$ until the extraction of RNA.

RNA extraction and complementary DNA (cDNA) synthesis. Total RNA was extracted from cell lines and samples using guanidinium thiocyanate as described previously (21). The quality of the RNA samples was confirmed. cDNA was synthesized from $8 \mu \mathrm{g}$ of total RNA using random hexamer primers and M-MLV reverse transcriptase (Invitrogen Corp.) as described previously (4).

Oligonucleotide primers for CKS2 cDNA amplification by reverse transcription polymerase chain reaction (RT-PCR).
The oligonucleotide primers for $C K S 2$ were as follows: Sense, 5'-TGTCTGAAGAGGAGTGGAGGA-3' and antisense, 5'-CAT GCACAGGTATGGATGAAA-3'. To avoid amplification of contaminating genomic DNA, these primers spanned more than two exons. The length of the amplified fragment was $241 \mathrm{bp}$. We used glyceraldehyde 3-phosphate dehydrogenase as the internal control. The primers for $G A P D H$ were as follows: Sense, 5'-TTGGTATCGTGGAAGGACTCA-3' and antisense, 5'-TGTCATCATATTTGGCAGGTT-3'. The amplification of $C K S 2$ was performed for 28 cycles of $1 \mathrm{~min}$ at $95^{\circ} \mathrm{C}, 1 \mathrm{~min}$ at $60^{\circ} \mathrm{C}$, and $1 \mathrm{~min}$ at $72^{\circ} \mathrm{C}$. The amplification of $G A P D H$ was performed for 25 cycles of $1 \mathrm{~min}$ at $95^{\circ} \mathrm{C}, 1 \mathrm{~min}$ at $56^{\circ} \mathrm{C}$, and $1 \mathrm{~min}$ at $72^{\circ} \mathrm{C}$. An $8-\mu \mathrm{l}$ aliquot of each amplified PCR product was electrophoresed on a $2 \%$ agarose gel containing ethidium bromide.

Real-time quantitative $R T-P C R$. Real-time quantitative RT-PCR amplification of $C K S 2$ and GAPDH mRNA in tissue samples was performed with the LightCycler System (Roche Applied Science, IN, USA) using the LightCycler-FastStart DNA Master SYBR-Green I kit (Roche Applied Science). Monitoring was performed according to the manufacturer's instructions, as described previously (22). A master mix was prepared on ice, containing $1 \mu \mathrm{l}$ of cDNA, $2 \mu \mathrm{l}$ of DNA Master SYBR-Green I mix, $50 \mathrm{ng}$ of primers and $2.4 \mu \mathrm{l}$ of $25 \mathrm{mM}$ $\mathrm{MgCl}_{2}$. The final volume was adjusted to $20 \mu \mathrm{l}$ with sterile water. After the mixture was loaded into the glass capillary tube, real-time quantitative RT-PCR was performed. The amplification conditions were as follows: Initial denaturation at $95^{\circ} \mathrm{C}$ for $10 \mathrm{~min}$, followed by 35 cycles of denaturation at $95^{\circ} \mathrm{C}$ for $10 \mathrm{sec}$, annealing at $62^{\circ} \mathrm{C}\left(60^{\circ} \mathrm{C}\right.$ for $\left.G A P D H\right)$ for $10 \mathrm{sec}$, and elongation at $72^{\circ} \mathrm{C}$ for $10 \mathrm{sec}$. To distinguish specific from non-specific products and primer dimers, melting curve analysis was carried out. To evaluate specific mRNA expression in the samples, a standard curve was produced for each run measuring four points of the human control cDNA (Clontech Laboratories). The concentration of each sample was calculated by observing its crossing point relative to the standard curve.

Immunohistochemistry. Immunohistochemical studies of CKS2 were performed on formalin-fixed, paraffin-embedded surgical specimens obtained from gastric cancer patients. The tissue sections were paraffinized and soaked in $0.01 \mathrm{M}$ sodium citrate buffer ( $\mathrm{pH}$ 7.4) for $20 \mathrm{~min}$ to retrieve the cell antigen. After blocking, the antigen-antibody reaction was incubated overnight at $4^{\circ} \mathrm{C}$. Tissue sections were immunohistochemically stained using the streptavidin-biotin peroxidase method (LSAB ${ }^{+}$system-HRP; Dako, Kyoto, Japan). All sections were counterstained with haematoxylin. The primary mouse monoclonal antibodies against CKS2 (Lifespan Biosciences Inc., WA, USA) were used at a dilution of 1:50.

Of the 109 total cases, we examined the CKS2 protein expression status in 26 available patient samples. In those 26 cases, 13 showed a high expression level of $C K S 2$ mRNA, whereas the remaining 13 cases showed a low expression level of $C K S 2$ mRNA. The border of the two groups was defined by the median of $C K S 2$ mRNA expression status in the tumor. All sections were independently examined by an investigator (H.I.). 
CKS2 RNA interference. CKS2-specific siRNA (Silencer ${ }^{\mathrm{TM}}$ Predesigned siRNA sense, 5'-GGAGACUUGGUGUCCAA CATT-3', and antisense, 5'-UGUUGGACACCAAGUCUC CTC-3') and negative control siRNA (Silencer Negative Control no. 1 siRNA) were purchased from Ambion, USA. The siRNA oligomer was diluted with Opti-MEM I medium (Invitrogen Corp.). The diluted siRNA oligomer was mixed with the diluted Lipofectamine ${ }^{\mathrm{TM}}$ RNAiMAX (Invitrogen Corp.) and incubated for $20 \mathrm{~min}$ at room temperature to allow siRNA-RNAiMAX complexes to form. The siRNA was added to each well to a final concentration of $125 \mathrm{pmol} / \mathrm{ml}$. Then, MKN74 cells were seeded at $3 \times 10^{5}$ cells per well in a final volume of $2 \mathrm{ml}$ in six-well, flat-bottom microtiter plates. The cells were incubated in $5 \% \mathrm{CO}_{2}$ at $37^{\circ} \mathrm{C}$.

In vitro proliferation assay. The cell proliferation rate was determined by 3-(4,5-dimethylthiazol-2-yl)-2,5-diphenyl tetrazolium bromide (MTT) assay (Roche Diagnostics Corp., IN, USA). The cells were plated at a density of $1 \times 10^{4}$ cells per well in 96-well, flat bottom microtiter plates and were harvested and counted on days zero to four. After incubation, $10 \mu \mathrm{l}$ of MTT labeling reagent were added to each well. The microtiter plate was incubated for $4 \mathrm{~h}$ in $5 \% \mathrm{CO}_{2}$ at $37^{\circ} \mathrm{C}$. Solubilization solution $(100 \mu \mathrm{l})$ was added to each well. The plate was allowed to stand overnight in an incubator in $5 \% \mathrm{CO}_{2}$ at $37^{\circ} \mathrm{C}$. After checking for complete solubilization of purple formazan crystals, the spectrophotometric absorbance of the samples was measured using a model 550 microplate reader (Bio-Rad Laboratories, CA, USA), at a wavelength of $570 \mathrm{~nm}$ corrected to $655 \mathrm{~nm}$. Each independent experiment was performed three times.

In vitro invasion assay. In vitro invasion assays were carried out using the CultreCoat ${ }^{\mathrm{TM}} 24$ Well BME-Coated Cell Invasion Assay (Trevigen, MD, USA). Cells were placed in the upper chamber, and the lower chamber was filled with $750 \mu 1$ of RPMI-1640 medium supplemented 10\% FBS. After $48 \mathrm{~h}$ of incubation in $5 \% \mathrm{CO}_{2}$ at $37^{\circ} \mathrm{C}$, the membranes were labeled with a calcein $\mathrm{AM}$ solution. The invasive cells that had migrated through the membrane to the lower surface were read in a fluorescence plate reader at a wavelength of $485 \mathrm{~nm}$ corrected to $530 \mathrm{~nm}$. Each independent experiment was performed three times.

In vitro migration assay. In vitro migration assays were carried out using the Cultrex ${ }^{\mathrm{TM}} 24$ Well Cell Migration Assay (Trevigen). Cells were placed in the upper chamber, and the lower chamber was filled with $750 \mu$ of RPMI-1640 medium supplemented with $10 \%$ FBS. After $48 \mathrm{~h}$ of incubation in 5\% $\mathrm{CO}_{2}$ at $37^{\circ} \mathrm{C}$, the membranes were labeled with a calcein $\mathrm{AM}$ solution. The cells that had migrated through the membrane to the lower surface were read in a fluorescence plate reader at a wavelength of $485 \mathrm{~nm}$ corrected to $530 \mathrm{~nm}$. Each independent experiment was performed three times.

Apoptosis assay. The cells were cultured at $3 \times 10^{5}$ cells per well in a final volume of $2 \mathrm{ml}$ in six-well, flat-bottom microtiter plates. The cells were incubated in $5 \% \mathrm{CO}_{2}$ at $37^{\circ} \mathrm{C}$. The cells were then washed and suspended in $0.5 \mathrm{ml}$ of binding buffer, and annexin V/fluorescein isothiocyanate/propidium iodide labeling was performed following the manufacturer's instructions (BD Biosciences). Analysis was performed with a FACScan instrument. A total of 5,000 cells were collected for each sample, and the data were analyzed with CellQuest software (Becton-Dickinson, San Jose, CA, USA). Each independent experiment was performed three times.

Flow cytometric analysis. The cells were harvested and rinsed twice with PBS. The cells were then fixed and permeated with the BD Active Caspase 3 Kit (Becton-Dickinson). Dissociated cells were stained with FITC-conjugated anti-caspase 3 antibody and incubated for $30 \mathrm{~min}$ at room temperature. A total of 10,000 cells were collected for each sample using FACScan (Becton-Dickinson), and the data were analyzed with CellQuest software. Each independent experiment was performed three times.

Western blot analysis. Total protein was extracted from the sample with PRO-PREP (iNtRON Biotechnology, Gyeonggi-do, Korea) on ice $30 \mathrm{~min}$. Aliquots of total protein were applied to $18 \%$ polyacrylamide gels (Bio-Rad Laboratories). After electrophoresis, the samples were electroblotted onto a pure nitrocellulose membrane (Bio-Rad) at $0.2 \mathrm{~A}$ for $2 \mathrm{~h}$ at $4^{\circ} \mathrm{C}$. Bax protein was detected using rabbit polyclonal antibody (Santa Cruz Biotechnology, CA, USA) at a dilution of 1:200. The blots were developed with horseradish peroxidase linked anti-rabbit immunoglobulin (GE Healthcare, CT, USA) at a dilution of 1:1,000. The protein level of Bax was normalized to the level of $\beta$-actin protein (Cytoskeleton, Inc., CO, USA) at a dilution of 1:1,000. The blots were developed with horseradish peroxidase-linked anti-mouse immunoglobulin (GE Healthcare) at a dilution of 1:1,000. Signals were detected using Western blotting detection ECL reagents (GE Healthcare).

Statistics. For continuous variables, the data were expressed as the means \pm standard deviation (SD). The relationship between $C K S 2$ mRNA expression and clinicopathological factors was analyzed using the $\chi^{2}$ test and the Student's t-test. Overall survival curves were plotted according to the KaplanMeier method and the generalized log-rank test was applied to analyze the survival curves. Prognostic factors were evaluated by univariate and multivariate analyses (Cox proportional hazard regression model). The cell proliferation assay was assessed with the Repeated ANOVA method. All differences were deemed significant at the level of $p<0.05$. Statistical analysis was performed using JMP software (SAS Institute Inc, Cary, NC, USA).

\section{Results}

CKS2 mRNA expression in gastric cancer cell lines and clinical samples. The expression of CKS2 mRNA in human gastric cancer cell lines and clinical samples was determined by RT-PCR (Fig. 1). The expression of $C K S 2 \mathrm{mRNA}$ was observed in all the human gastric cancer cell lines that were surveyed (KATOIII, MKN1, MKN7, MKN28, MKN45, MKN74, NUGC3 and NUGC4) (Fig. 1A). We also performed RT-PCR analyses of $C K S 2$ in gastric cancer samples and paired normal samples obtained from seven patients. A significantly higher expression of $C K S 2$ mRNA was observed 
A. $\begin{array}{lllllllllll}\text { KATOIII } & \text { MKNI } & \text { MKN7 } & \text { MKN28 } & \text { MKN45 } & \text { MKN74 NUGC3 } & \text { NUGC4 } & \text { n } & \text { p } & \text { m }\end{array}$

CKS2

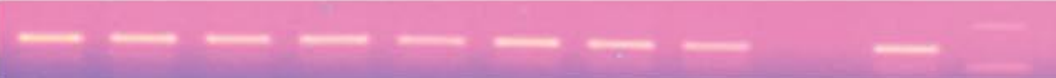

GAPDH
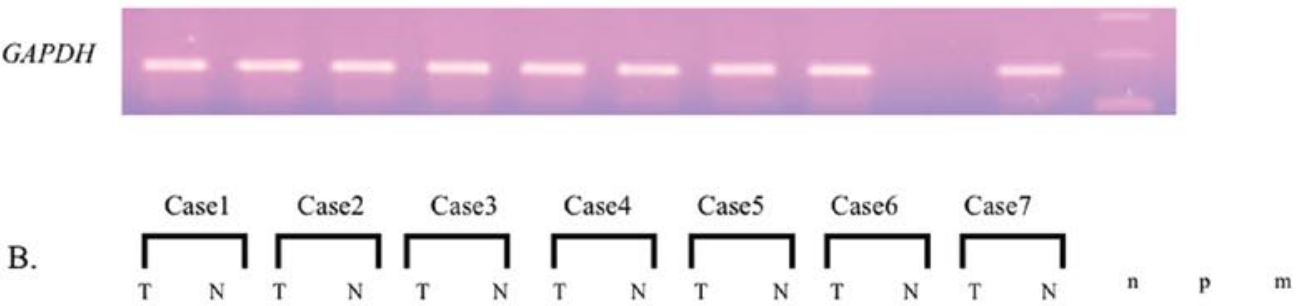

CKS2

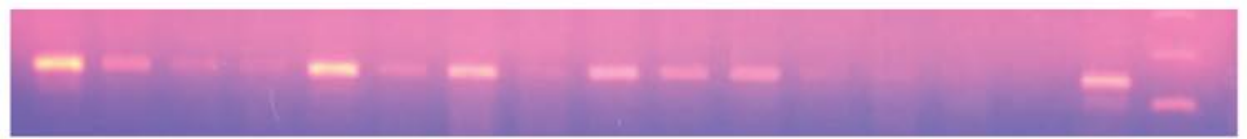

GAPDH

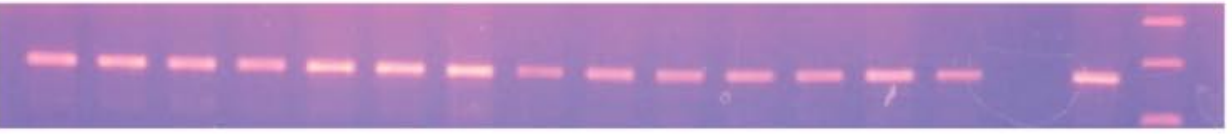

C.

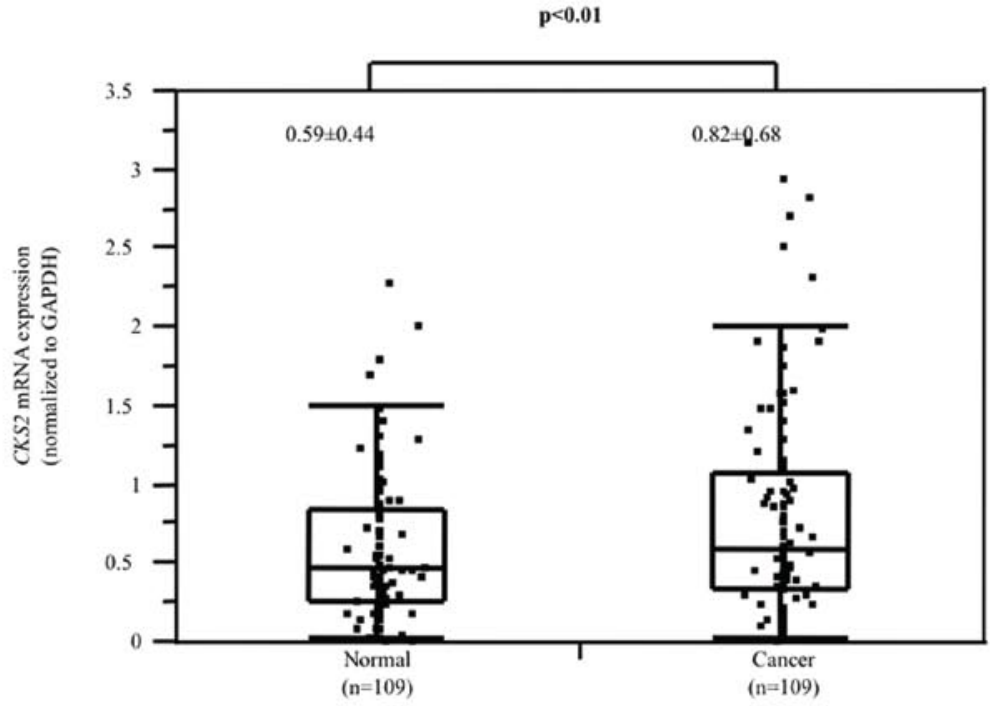

D.

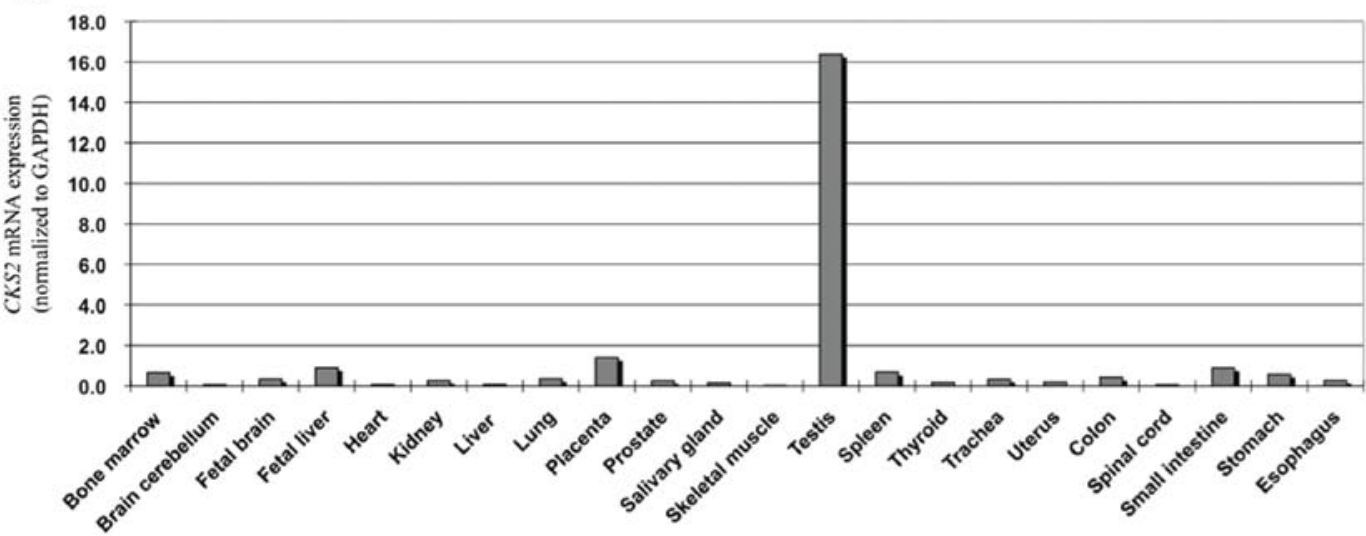

Figure 1. Gene expression of $C K S 2$ in gastric cancer and normal cells. CKS2 and GAPDH mRNA expression in eight human gastric cancer cell lines (A) and seven clinical samples (B) by RT-PCR. Product sizes of $C K S 2$ and GAPDH were 241 and 270 bp, respectively. T, tumor tissue; N, normal tissue; n, negative control; $\mathrm{p}$, positive control; $\mathrm{m}$, marker. (C) Mean expression levels of $C K S 2$ in cancer tissue were significantly higher than the levels in normal tissue ( $\mathrm{p}<0.01$, Student's t-test). The data represent the means \pm SD. (D) The highest expression was observed in the testis. In the digestive organs, the stomach, colon and small intestines, the expression was lower.

in the tumor tissues than in the paired normal tissues (Fig. 1B). We confirmed the expression of the CKS2 mRNA in clinical samples by real-time quantitative RT-PCR (Fig. 1C). Real- time quantitative RT-PCR analysis on 109 paired clinical samples showed that 62 of 109 cases (56.9\%) exhibited higher levels of $C K S 2$ mRNA in the tumors than in the paired normal 
A.

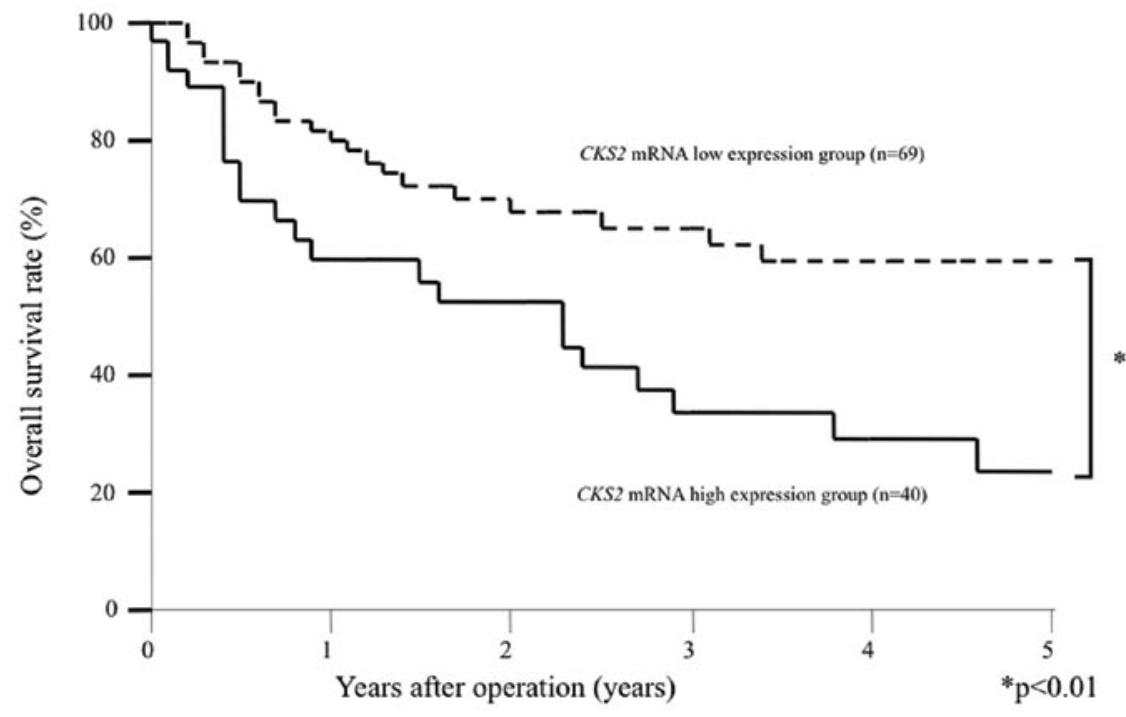

B.

i

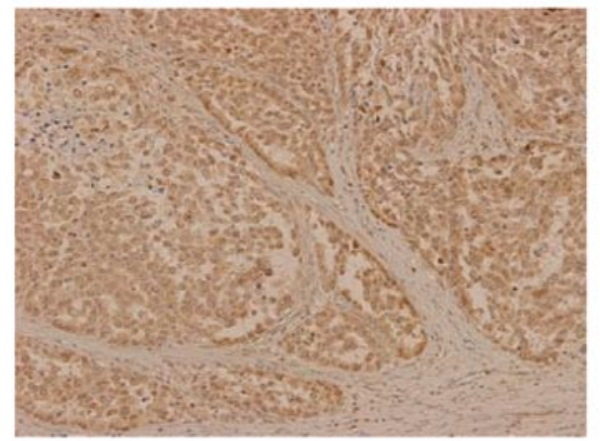

ii

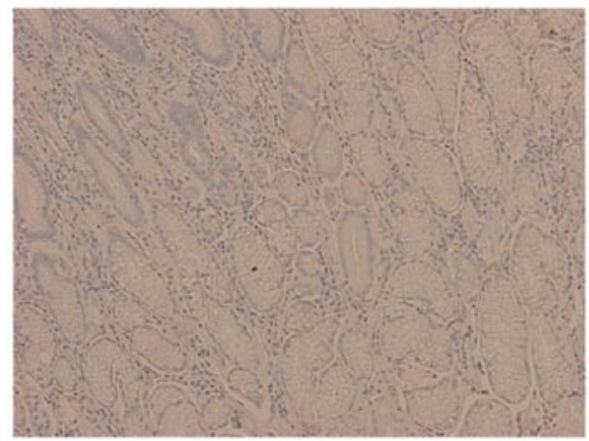

Figure 2. Kaplan-Meier survival curves in patients with gastric cancer according to the levels of $C K S 2 \mathrm{mRNA}$ expression, and CKS2 expression in clinical specimens. (A) There was a significant difference between the patients with $C K S 2 \mathrm{mRNA}$ high and low expression (p<0.01). (B) Immunohistochemistry with CKS2 antibody in gastric cancer cells (i) and non-cancer cells (ii). CKS2 protein was predominantly expressed in gastric cancer cells. In cancer cells, the protein expression of CKS2 occurred mainly in the nucleus (i and ii, high power field; x200).

samples. The mean expression value of $C K S 2 \mathrm{mRNA}$ in the tumor samples, $0.82 \pm 0.68$ (mean $\pm \mathrm{SD}$, normalized to $G A P D H$ gene expression), was significantly higher than the value, $0.59 \pm 0.44$, in the corresponding normal samples $(\mathrm{p}<0.01$; Student's $t$ test). For further analysis of tumors, the cases were divided into high $(n=40)$ and low $(n=69)$ expression groups according to the average $C K S 2$ mRNA expression status in the tumor. The cut-off value was the most significant one for prognostic prediction by log-rank plot analysis.

CKS2 mRNA expression in human normal tissues. Quantitative real-time RT-PCR was performed using the Human Total RNA Master Panel (Clontech, Palo Alto, CA, USA) to characterize $C K S 2$ mRNA expression (Fig. 1D). CKS 2 expression in the testis was extremely high. In the digestive organs, the stomach, colon and small intestines, the expression was lower.

The clinicopathological significance of CKS 2 mRNA expression in gastric cancer. The clinical samples were divided into two expression groups as mentioned previously. The expression of CKS 2 mRNA in human gastric cancer and the correlation with clinicopathological factors are shown in Table I. Five of these factors, i.e., tumor size, the incidence of serosal invasion, the incidence of lymph node metastasis, the incidence of liver metastasis, and the incidence of advanced stage cancer (according to the criteria of the Japanese Classification of Gastric Carcinoma) were significantly different in the high expression group when compared to the low expression group. On the contrary, clinicopathological factors, such as age, gender, histological grade, lymphatic invasion, venous invasion, peritoneal dissemination and distant metastasis were not significantly different between the high and low expression groups.

Relationship between CKS2 mRNA expression and prognosis. The patients in the $C K S 2$ high expression group had a significantly poorer prognosis than those in the $C K S 2$ low expression group (Fig. 2A, p<0.01). The overall five-year survival rate 
Table I. Clinicopathological correlations of CKS2 mRNA expression in 109 gastric cancer patients.

\begin{tabular}{|c|c|c|c|c|}
\hline Variables & Number & $\begin{array}{l}\text { High expression } \\
\qquad(\mathrm{n}=40)\end{array}$ & $\begin{array}{l}\text { Low expression } \\
\quad(\mathrm{n}=69)\end{array}$ & P-value \\
\hline Age (mean \pm SD) & & $63.2 \pm 10.8$ & $67.4 \pm 11.1$ & 0.16 \\
\hline $\begin{array}{l}\text { Gender } \\
\text { Male } \\
\text { Female }\end{array}$ & $\begin{array}{l}74 \\
35\end{array}$ & $\begin{array}{l}26 \\
14\end{array}$ & $\begin{array}{l}48 \\
21\end{array}$ & 0.62 \\
\hline $\begin{array}{l}\text { Histological grade } \\
\text { Well } \\
\text { Moderate } \\
\text { Poor } \\
\text { Other }\end{array}$ & $\begin{array}{l}16 \\
36 \\
43 \\
12\end{array}$ & $\begin{array}{r}4 \\
15 \\
16 \\
4\end{array}$ & $\begin{array}{r}12 \\
21 \\
27 \\
8\end{array}$ & 0.99 \\
\hline $\begin{array}{l}\text { Tumor size (maxin } \\
\text { Small }(\leq 5 \mathrm{~cm}) \\
\text { Large }(>5 \mathrm{~cm})\end{array}$ & $\begin{array}{l}50 \\
54\end{array}$ & $\begin{array}{l}12 \\
27\end{array}$ & $\begin{array}{l}38 \\
27\end{array}$ & $<0.01$ \\
\hline $\begin{array}{c}\text { Serosal invasion } \\
\text { Absent (T1, T2) } \\
\text { Present }(\mathrm{T} 3, \mathrm{~T} 4)\end{array}$ & $\begin{array}{l}38 \\
71\end{array}$ & $\begin{array}{r}9 \\
31\end{array}$ & $\begin{array}{l}29 \\
40\end{array}$ & $<0.05$ \\
\hline $\begin{array}{l}\text { Lymph node metas } \\
\text { Absent } \\
\text { Present }\end{array}$ & $\begin{array}{l}41 \\
68\end{array}$ & $\begin{array}{r}8 \\
32\end{array}$ & $\begin{array}{l}33 \\
36\end{array}$ & $<0.01$ \\
\hline $\begin{array}{l}\text { Lymphatic invasio } \\
\text { Absent } \\
\text { Present }\end{array}$ & $\begin{array}{l}35 \\
74\end{array}$ & $\begin{array}{l}10 \\
30\end{array}$ & $\begin{array}{l}25 \\
44\end{array}$ & 0.22 \\
\hline $\begin{array}{l}\text { Venous invasion } \\
\text { Absent } \\
\text { Present }\end{array}$ & $\begin{array}{l}81 \\
28\end{array}$ & $\begin{array}{l}28 \\
12\end{array}$ & $\begin{array}{l}53 \\
16\end{array}$ & 0.44 \\
\hline $\begin{array}{l}\text { Liver metastasis } \\
\text { Absent } \\
\text { Present }\end{array}$ & $\begin{array}{r}102 \\
6\end{array}$ & $\begin{array}{r}35 \\
5\end{array}$ & $\begin{array}{r}67 \\
1\end{array}$ & $<0.05$ \\
\hline $\begin{array}{l}\text { Peritoneal dissemir } \\
\text { Absent } \\
\text { Present }\end{array}$ & $\begin{array}{r}90 \\
18\end{array}$ & $\begin{array}{r}31 \\
9\end{array}$ & $\begin{array}{r}59 \\
9\end{array}$ & 0.3 \\
\hline $\begin{array}{l}\text { Distant metastasis } \\
\text { Absent } \\
\text { Present }\end{array}$ & $\begin{array}{r}104 \\
3\end{array}$ & $\begin{array}{r}37 \\
2\end{array}$ & $\begin{array}{r}67 \\
1\end{array}$ & 0.28 \\
\hline $\begin{array}{l}\text { Stage classificaion } \\
\text { I and II } \\
\text { III and IV }\end{array}$ & $\begin{array}{l}57 \\
51\end{array}$ & $\begin{array}{l}16 \\
24\end{array}$ & $\begin{array}{l}41 \\
27\end{array}$ & $<0.05$ \\
\hline $\begin{array}{l}\text { Prognosis } \\
\text { Alive } \\
\text { Dead }\end{array}$ & $\begin{array}{l}66 \\
43\end{array}$ & $\begin{array}{l}18 \\
22\end{array}$ & $\begin{array}{l}48 \\
21\end{array}$ & $<0.05$ \\
\hline
\end{tabular}

Numbers in bold indicate statistical significance.

was significantly higher in the $C K S 2$ low expression group (59.9\%) than in the CKS2 high expression group (23.9\%) $(\mathrm{p}<0.01)$. Table II presents univariate and multivariate analyses of factors related to patient prognosis. Multivariate regression analysis indicated that inclusion in the CKS2 mRNA high expression group [relative risk (RR), 1.41; 95\% confidence interval (CI), 1.01-1.97; $\mathrm{p}<0.05)$ ] was an independent predictor of overall survival, as well as lymph node metastasis (RR,
2.78; 95\% CI, 1.43-7.20; $\mathrm{p}<0.01$ ), liver metastasis (RR, 2.19; 95\% CI, 1.09-4.06; $\mathrm{p}<0.03$ ), and peritoneal dissemination (RR, 2.57; 95\% CI, 1.65-4.12; $\mathrm{p}<0.01$ ). Among the 109 cases of gastric cancer entered in this study, 49 cases had postoperative chemotherapy ( $5 \mathrm{FU}$ for 42 cases and other treatments for seven cases), 48 did not, and the remaining 12 cases are unknown. The patients who received post-operative chemotherapy had a significantly poorer prognosis than those who 
Table II. Univariate and multivariate analysis for overall survival.

\begin{tabular}{|c|c|c|c|c|c|}
\hline \multirow[b]{2}{*}{ Variables } & \multirow[b]{2}{*}{ No. of patients } & \multicolumn{2}{|c|}{ 5-Year survival } & \multicolumn{2}{|c|}{ Multivariate analysis } \\
\hline & & Rate $(\%)$ & P-value & Relative risk (CI) & P-value \\
\hline \multicolumn{6}{|l|}{ Age } \\
\hline$\leq 65$ & 40 & 41.9 & 0.55 & & \\
\hline$>65$ & 68 & 51.1 & & & \\
\hline \multicolumn{6}{|l|}{ Gender } \\
\hline Male & 74 & 41.3 & 0.39 & & \\
\hline Female & 35 & 57.6 & & & \\
\hline \multicolumn{6}{|c|}{ Histological grade } \\
\hline Well & 16 & 49.7 & 0.49 & & \\
\hline Moderate & 36 & 47.1 & & & \\
\hline Poor & 43 & 41.3 & & & \\
\hline Other & 12 & 50.5 & & & \\
\hline \multicolumn{6}{|c|}{ Tumor size (maximal diameter) } \\
\hline Small $(\leq 5 \mathrm{~cm})$ & 50 & 58.3 & 0.03 & $0.91(0.63-1.34)$ & 0.63 \\
\hline Large $(>5 \mathrm{~cm})$ & 54 & 33.0 & & & \\
\hline \multicolumn{6}{|l|}{ Serosal invasion } \\
\hline Absent & 38 & 89.6 & $<0.01$ & $1.61(0.88-3.47)$ & 0.13 \\
\hline Present & 71 & 34.0 & & & \\
\hline \multicolumn{6}{|c|}{ Lymph node metastasis } \\
\hline Absent & 41 & 91.3 & $<0.01$ & $2.78(1.43-7.20)$ & $<0.01$ \\
\hline Present & 68 & 22.9 & & & \\
\hline \multicolumn{6}{|c|}{ Lymphatic invasion } \\
\hline Absent & 35 & 91.4 & $<0.01$ & $1.22(0.60-3.22)$ & 0.63 \\
\hline Present & 74 & 29.6 & & & \\
\hline \multicolumn{6}{|l|}{ Venous invasion } \\
\hline Absent & 81 & 59.3 & $<0.01$ & $1.07(0.69-1.62)$ & 0.77 \\
\hline Present & 28 & 12.3 & & & \\
\hline \multicolumn{6}{|l|}{ Liver metastasis } \\
\hline Absent & 102 & 48.2 & $<0.01$ & $2.19(1.09-4.06)$ & 0.03 \\
\hline Present & 6 & 0 & & & \\
\hline \multicolumn{6}{|c|}{ Peritoneal dissemination } \\
\hline Absent & 90 & 57.5 & $<0.01$ & $2.57(1.65-4.12)$ & $<0.01$ \\
\hline Present & 18 & 0 & & & \\
\hline \multicolumn{6}{|c|}{ Distant metastasis } \\
\hline Absent & 104 & 47.7 & $<0.01$ & & \\
\hline Present & 3 & 0 & & & \\
\hline \multicolumn{6}{|c|}{ Stage classificaion } \\
\hline I and II & 57 & 80.2 & $<0.01$ & & \\
\hline III and IV & 51 & 12.9 & & & \\
\hline \multicolumn{6}{|c|}{$\mathrm{T}$ average of $C K S 2$ expression } \\
\hline Low & 69 & 59.9 & 0.02 & $1.41(1.01-1.97)$ & $<0.05$ \\
\hline High & 40 & 23.9 & & & \\
\hline
\end{tabular}

Numbers in bold indicate statistical significance.

did not receive it $(\mathrm{p}=0.01)$. However, when patients were analyzed for $C K S 2$ mRNA expression and the response to post-operative chemotherapy, no significant correlation was observed ( $\mathrm{p}=0.43)$. Thus, the $C K S 2$ mRNA expression did not affect the outcome of post-operative chemotherapy, but it was related to prognosis. 


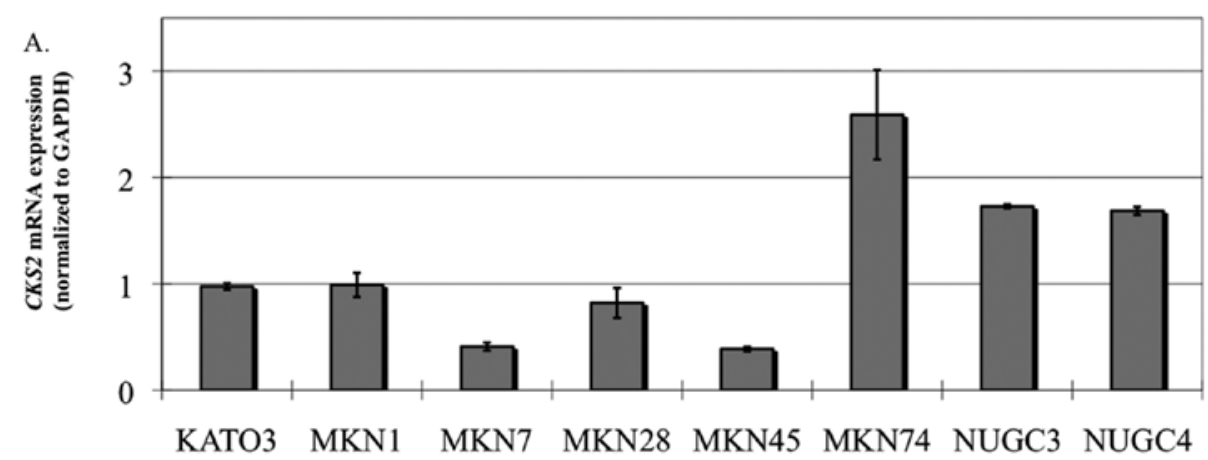

B.

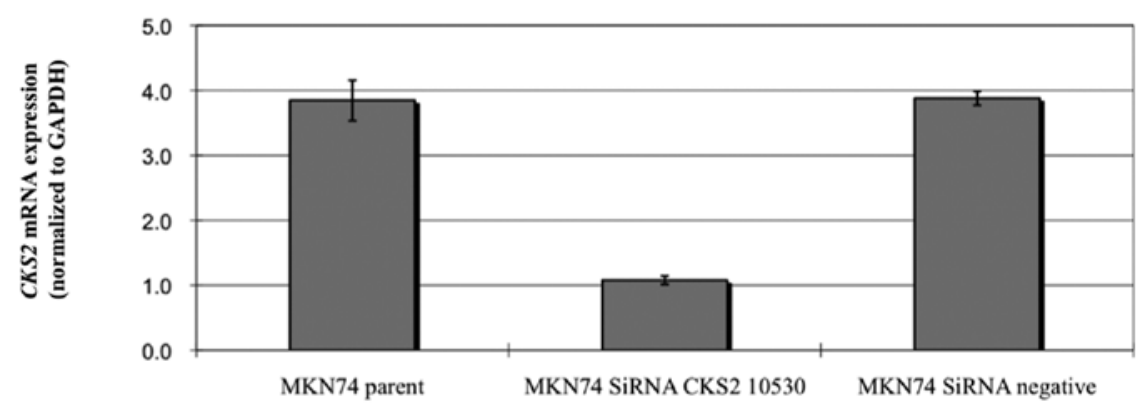

C.

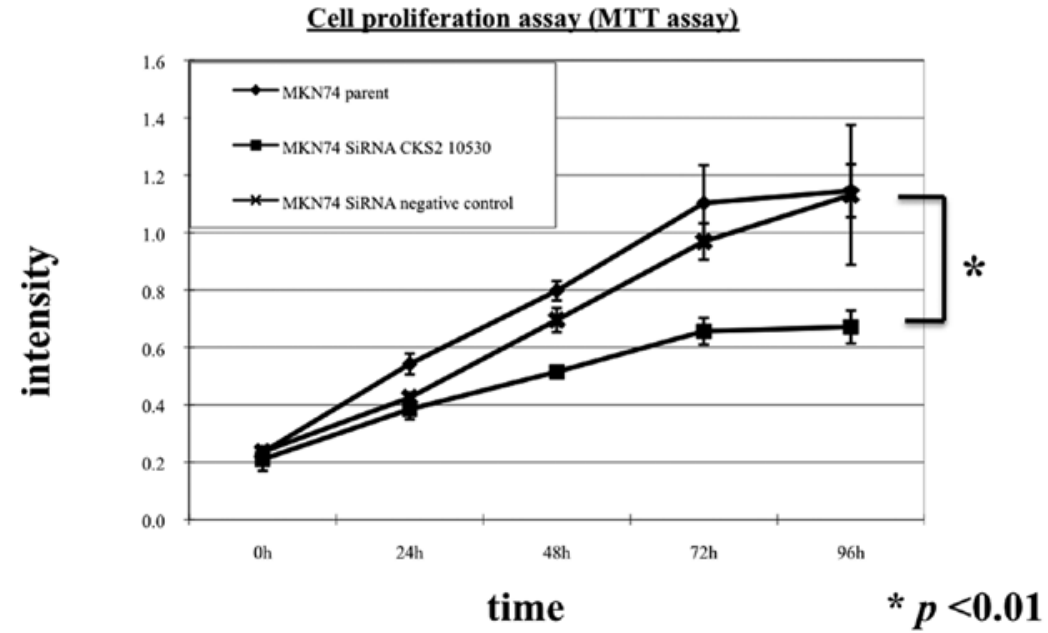

Figure 3. CKS2 mRNA expression in cell lines and the effect of siRNA treatment. (A) CKS2 mRNA expression in several gastric cancer cell lines by real-time RT-PCR. The highest expression was observed in the MKN74 gastric cancer cell line. (B) CKS2 mRNA expression in MKN74 cells by real-time RT-PCR. The mean expression value of $C K S 2 \mathrm{mRNA}$ in CKS2-siRNA suppressed cells, $1.08 \pm 0.06$ (mean $\pm \mathrm{SD}$, normalized to GAPDH gene expression), was significantly lower than the value, $3.88 \pm 0.16$, in the siRNA-negative control $(\mathrm{p}<0.01)$. (C) MTT assay. In vitro proliferation rate of $C K S 2$-suppressed cells. $C K S 2$-suppressed cells were less proliferative than the siRNA-negative control $(\mathrm{p}<0.01)$. The data represent the means $\pm \mathrm{SD}$.

Immunohistochemistry of CKS2 expression. The expression of the CKS2 protein was evaluated by immunohistochemistry analysis of resected gastric cancer samples. Staining of CKS2 was markedly stronger in the human gastric cancer tissues than in the corresponding normal tissues. The expression of CKS2 was localized to the cell nucleus (Fig. 2B).

In 13 cases with above average levels of $C K S 2$ mRNA expression, CKS2 staining in the cancer cells was strong in 9 cases, and moderate or weak in 4 cases. In contrast, in 13 cases with below average expression levels of $C K S 2 \mathrm{mRNA}$, CKS2 staining was strong in 4 cases, and moderate or weak in 9 cases. Thus, this shows that the level of expression of $C K S 2$ mRNA was associated with the level of protein expression $(\mathrm{p}<0.05)$.
The effect of CKS2 gene suppression in a gastric cancer cell line. The highest $C K S 2$ expression was found in MKN74 cells by real-time quantitative RT-PCR (Fig. 3A). Therefore, we used the MKN74 cell line for subsequent experiments. CKS2specific siRNA-suppressed cells were established. The suppression of $C K S 2$ expression was confirmed with real-time quantitative RT-PCR (Fig. 3B). We measured $C K S 2 \mathrm{mRNA}$ expression $72 \mathrm{~h}$ after the $C K S 2$ siRNA-RNAiMAX complex was formed. The mean expression value of $C K S 2 \mathrm{mRNA}$ in CKS2-siRNA-suppressed cells, $1.08 \pm 0.06$ (mean $\pm \mathrm{SD}$, normalized to $G A P D H$ gene expression), was significantly lower than the value for the siRNA-negative control, 3.88 \pm 0.16 $(\mathrm{p}<0.01$; Student's $\mathrm{t}$ test). We analyzed whether the suppression of $C K S 2$ altered the growth rate of the MKN74 gastric cancer 
D.

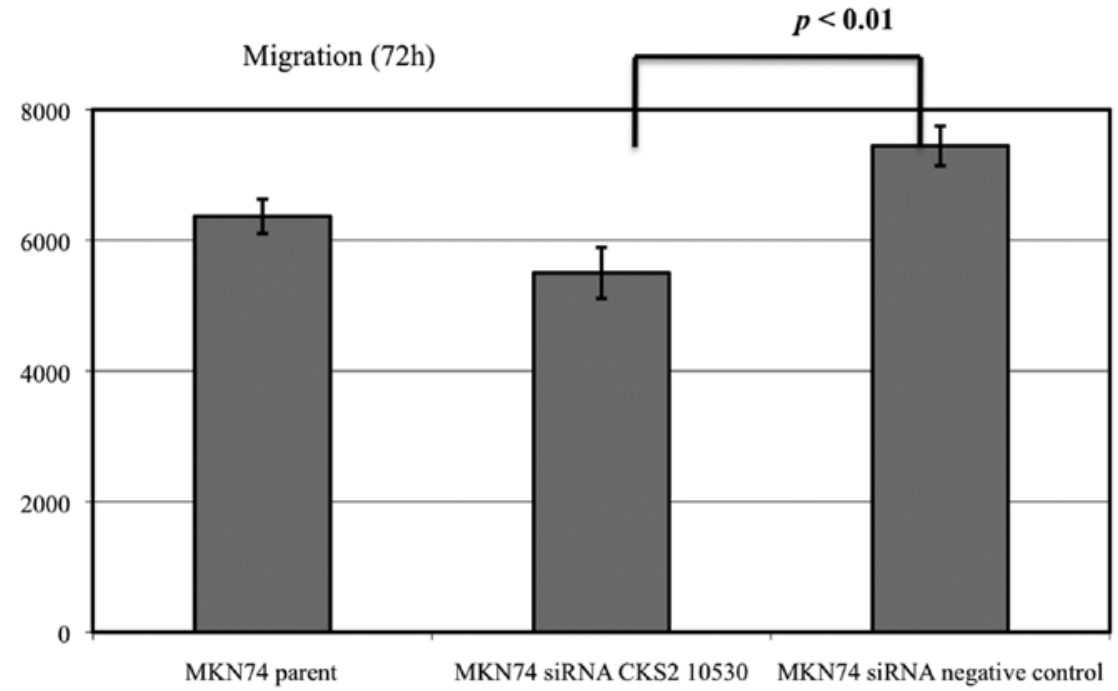

E.

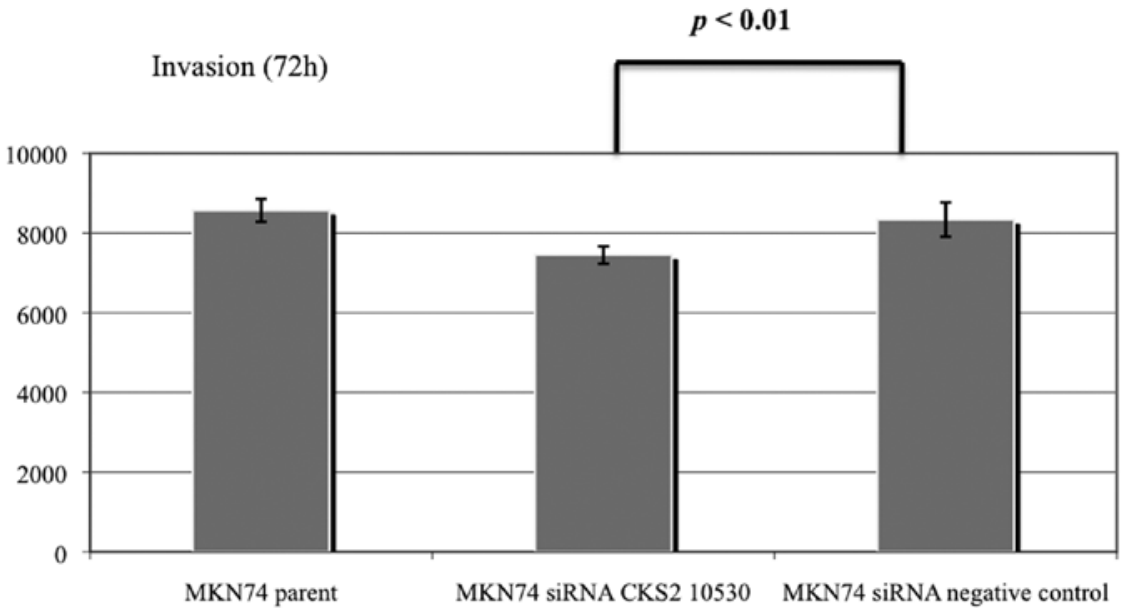

Figure 3. Continued. (D) Migration assay. The migration of $C K S 2$-siRNA cells was significantly less than the siRNA-negative control (p $<0.01)$. The data represent the means \pm SD. (E) Invasion assay. The invasiveness of $C K S 2$-siRNA cells was significantly less than the siRNA-negative control (p<0.01). The data represent the means $\pm \mathrm{SD}$.

cell line. As shown in Fig. 3C, there was a significant difference in the growth rate between CKS2-siRNA suppressed cells and the siRNA negative-control $(\mathrm{p}<0.01)$.

In the clinicopathological studies, we found that tumor size was significantly larger in the $C K S 2$ high expression group than in the $C K S 2$ low expression group and the incidence of serosal invasion was significantly higher in the high expression group than in the low expression group (Table I). To verify these findings in an in vitro assay, we examined the migratory and invasive potential of $C K S 2$-siRNA cells using in vitro migration and Matrigel invasion assays. The migration assay showed that $C K S 2$-siRNA cells had significantly less migratory capacity than the siRNA-negative control (p<0.01) (Fig. 3D). The invasion assay showed that $C K S 2$-siRNA cells were significantly less invasive than the siRNA-negative control $(\mathrm{p}<0.01)$ (Fig. 3E). Thus, a high expression of CKS2 enhanced tumor migration and invasiveness.

In addition, we found that $C K S 2$-siRNA cells were dramatically altered in their morphological appearance. Most of the transfected cells became rounded and loosely attached to the culture surface (data not shown). The cells were stained with the annexin V/propidium iodide dye $72 \mathrm{~h}$ after the $C K S 2$ -
siRNA-RNAiMAX complex was formed. The assays showed that $C K S 2$-siRNA cells had a higher frequency of apoptosis (25.1\%) than the siRNA-negative control (12.9\%) (Fig. 4A). As shown in Fig. 4B, there was a significant difference in the percentages of apoptotic cells between $C K S 2$-siRNA cells and the siRNA-negative control $(\mathrm{p}<0.01)$. We examined caspase 3 expression in $C K S 2$-siRNA cells by flow cytometry. $C K S 2$ siRNA cells had increased caspase 3 activity (10.8\%) compared to the siRNA-negative control (2\%), indicating that the suppression of CKS2 expression increased caspase 3 activity by at least five-fold (Fig. 4C). To further confirm these results, Western blot analyses were carried out to assess the abundance of apoptotic markers at the protein levels. It was apparent that the knockdown of $C K S 2$ expression increased Bax expression at the protein level (Fig. 4D). The pathways from CKS2 to caspase 3 and Bax, are unidentified, but these results show that apoptosis is induced by inhibiting CKS2 expression.

\section{Discussion}

In the patients studied here, $C K S 2$ was overexpressed in the gastric cancer tissues compared to the normal tissues of the 
A.

\section{Apoptosis assav (72h)}

MKN74 parent

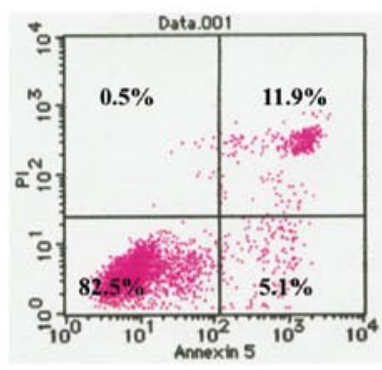

MKN74 siRNA CKS2 10530

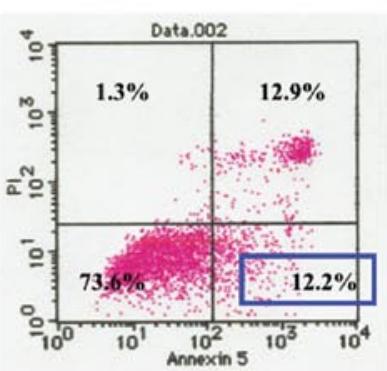

MKN74 siRNA negative control

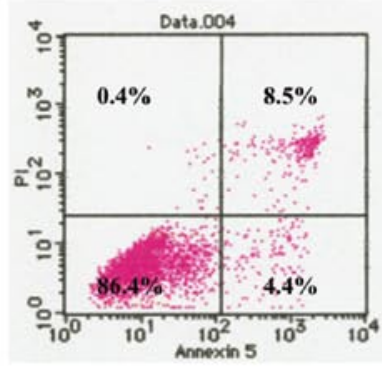

B.

Annexin V (+), PI (-) (72h)

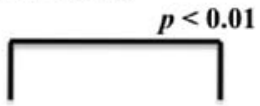

Annexin V (+) (72h)

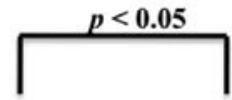

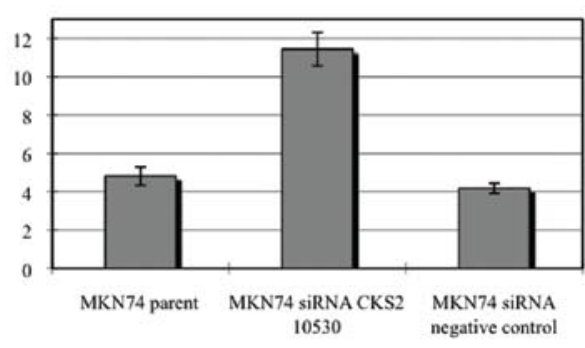

C.

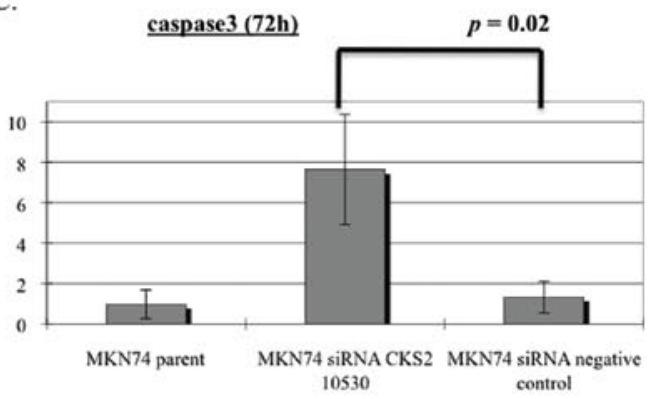

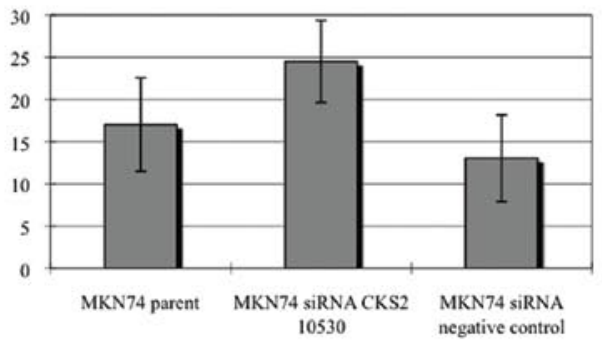

D.

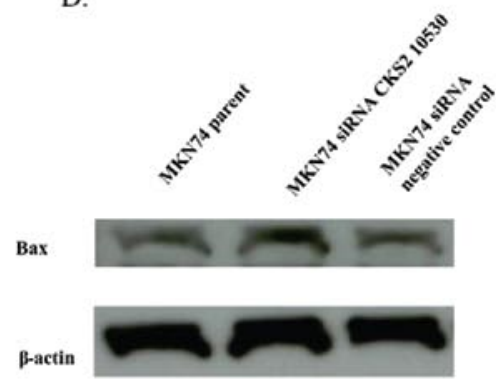

Figure 4. CKS2 and apoptosis. (A) Apoptosis assay. The apoptotic frequencies were measured by annexin $\mathrm{V}$ and propidium iodide (PI) staining. Apoptotic cells were calculated as UR + LR (CKS2-siRNA: UL, 1.3\%; UR, 12.9\%; LL, 73.6\%; LR, 12.2\%. siRNA-negative control: UL, 0.4\%; UR, 8.5\%; LL, 86.4\%; LR, 4.4\%). The proportion of apoptotic cells after $C K S 2$-siRNA treatment (25.1\%) was more than the siRNA-negative control (12.9\%). (UL, upper left; UR, upper right; LL, lower left; LR, lower right) (B) The apoptotic frequencies of CKS2-siRNA cells and the siRNA-negative control. The apoptotic frequencies of CKS2-siRNA cells were significantly more than those of the siRNA-negative control $(\mathrm{p}<0.01)$. The data represent the means $\pm \mathrm{SD}$. (C) The frequencies of caspase 3-positive cells in $C K S 2$-siRNA cultures and the siRNA-negative control. The caspase 3 activity of $C K S 2$-siRNA cells was significantly more than that of the siRNA-negative control $(\mathrm{p}=0.02)$. The data represent the means $\pm \mathrm{SD}$. (D) Bax expression of CKS2-siRNA cells and siRNA-negative control. CKS2siRNA cells overexpressed Bax compared to the siRNA-negative control.

stomach. Similar results have been reported in the analyses of other cancers. For example, Li et al studied colon cancer with genome-wide cDNA microarray, reporting that $C K S 2$ was overexpressed in the cancer tissues compared to the non-cancer tissues of the colon, and was overexpressed in cancers with liver metastasis compared to those without liver metastasis (23). Wong et al and De Wit et al reported similar results in human cervical cancers and malignant melanoma, respectively $(1,24)$. Scrideli CA et al and Rickman et al reported similar results in human gliomas $(25,26)$. Furthermore, $C K S 2$ was overexpressed in bladder cancers that were invasive compared to those that were superficial (27).

This study demonstrates that $C K S 2$ mRNA expression status is associated with tumor size, depth of tumor invasion 
in the gastric wall, lymph node metastasis and liver metastasis. The cases with high $C K S 2$ mRNA expression tended toward larger tumor size, deeper wall invasion, positive lymph node metastasis, positive liver metastasis and, as a result, poorer prognosis compared to those with low expression.

The expression of CKS2 correlated with tumor size. The suppression of CKS2 expression by siRNA showed lower cellular proliferation and migration (Fig. 3). Cells treated with CKS2-siRNA altered their cell morphology (data not shown). We hypothesized that apoptosis would be induced by the inhibition of $C K S 2$ expression. The suppression of $C K S 2$ expression increased the annexin $\mathrm{V}$-positive cell populations, caspase 3 activity and Bax expression at the protein levels (Fig. 4). These results show that apoptosis is induced by inhibiting CKS 2 expression. Our data are consistent with ones from other studies on other cancers (28-30).

The expression of $C K S 2$ correlated with serosal invasion. The suppression of $C K S 2$ expression by siRNA showed lower invasiveness (Fig. 3E). These results are consistent with ones from other studies on bladder (27) and colon cancer (31). It is important to know the extent of invasion at the time of treatment of gastric cancer. Endoscopic mucosal resection (EMR) and endoscopic submucosal dissection (ESD) are being introduced to routine clinical practices. The determination of treatment strategy depends in part on the extent of wall invasion. For example, if invasion of the wall is limited to the mucosa, EMR or ESD would be applicable. However, if the invasion reaches the middle or deep layers of the submucosa, more aggressive surgery would be required. We are currently examining CKS2 expression in biopsy specimens that were obtained prior to surgery.

This study found that the expression of $C K S 2$ correlated with lymph node metastasis. This finding is also consistent with findings from other studies on cervical cancers (1). We previously analyzed genes related to lymph node metastasis in human esophageal cancers. Using laser microdissection techniques and cDNA microarray, several genes were identified and found to be differentially expressed between the lymph node-positive and -negative primary tumors. One of these genes was $C K S 2$ (32). Thus, we consider that this gene could be associated with lymph node metastasis in a wide variety of cancers. Patients suitable for endoscopic treatments are selected by the pre-operative diagnosis of lymph node metastasis, such as macroscopic type, tumor size, presence of an ulcer, and histology of biopsy specimens. However, it is very difficult to diagnose some patients correctly, and they actually do have lymph node metastasis before surgical intervention. By incorporating the quantitative analysis of $C K S 2$ gene expression, pre-operative selection of patients without lymph node metastasis could be possible.

Univariate analysis demonstrated that the following were prognostic factors: Tumor size, depth of wall invasion, lymph node metastasis, lymph vessel and vascular vessel invasions, liver metastasis, peritoneal dissemination and $C K S 2$ expression status. Multivariate analysis demonstrated that $C K S 2$ expression status, lymph node metastasis, liver metastasis and peritoneal dissemination were independent prognostic factors for overall survival in the Cox proportional hazard regression model. To our knowledge, this is the first study reporting a correlation between CKS2 expression and prognosis in gastric cancer. In the majority of gastric cancer reports, gene expression is secondary to TNM stage classification as a prognostic marker. As its expression is an independent prognostic factor, the expression profile of CKS2 could contribute to the creation of a new clinical classification system predicting lymph node metastasis.

In conclusion, we demonstrate that the expression of $C K S 2$ in gastric cancer is elevated relative to levels in normal tissue, and that $C K S 2$ mRNA overexpression is associated with tumor differentiation, lymph node metastasis, distant metastasis, peritoneal dissemination and poor prognosis. In particular, $C K S 2$ mRNA overexpression is associated with prognosis, as shown by multivariate analyses. Therefore, CKS2 could be a useful predictive marker of lymph node metastasis, which could permit minimally invasive and curative treatments combining EMR and ESD in early gastric cancer.

\section{Acknowledgments}

We thank T. Shimooka, K. Ogata, M. Kasagi, Y. Nakagawa, and T. Kawano for their excellent technical assistance. This study was supported in part by the following grants and foundations: The Core Research for Evolutional Science and Technology (CREST), Japan Science and Technology Agency (JST); Grants-in-Aid for Scientific Research (grant nos. 21679006, 20390360, 20591547, 20590313, 21591644, 20591547, 20790960, 21791297, 20659209, 21592014 and 21229015); a Grant-in-Aid for Scientific Research on Priority Areas from the Ministry of Education, Culture, Sports, Science and Technology (MEXT) (grant no 18015039); the Third Term Comprehensive Ten-year Strategy for Cancer Control (grant no. 16271201); the New Energy and Industrial Technology Development Organization (NEDO) Technological Development for Chromosome Analysis; the Ministry of Education, Culture, Sports, Science and Technology of Japan for Scientific Research on Priority Areas, Cancer Translational Research Project, Japan; and also a grant from the Clinical Research Foundation (2008-2010).

\section{References}

1. Wong YF, Cheung TH, Tsao GS, et al: Genome-wide gene expression profiling of cervical cancer in Hong Kong women by oligonucleotide microarray. Int J Cancer 118: 2461-2469, 2006.

2. Mrena J, Wiksten JP, Kokkola A, Nordling S, Haglund C and Ristimaki A: Prognostic significance of cyclin A in gastric cancer. Int J Cancer 119: 1897-1901, 2006.

3. Bani-Hani KE, Almasri NM, Khader YS, Sheyab FM and Karam HN: Combined evaluation of expressions of cyclin $E$ and p53 proteins as prognostic factors for patients with gastric cancer. Clin Cancer Res 11: 1447-1453, 2005.

4. Masuda TA, Inoue H, Sonoda $\mathrm{H}$, et al: Clinical and biological significance of S-phase kinase-associated protein 2 (Skp2) gene expression in gastric carcinoma: modulation of malignant phenotype by Skp2 overexpression, possibly via p27 proteolysis. Cancer Res 62: 3819-3825, 2002.

5. Welcker M, Orian A, Jin J, et al: The Fbw7 tumor suppressor regulates glycogen synthase kinase 3 phosphorylation-dependent c-Myc protein degradation. Proc Natl Acad Sci USA 101: 9085-9090, 2004.

6. Hayles J, Beach D, Durkacz B and Nurse P: The fission yeast cell cycle control gene cdc2: isolation of a sequence suc1 that suppresses cdc2 mutant function. Mol Gen Genet 202: 291-293, 1986.

7. Hadwiger JA, Wittenberg C, Mendenhall MD and Reed SI: The Saccharomyces cerevisiae CKS1 gene, a homolog of the Schizosaccharomyces pombe suc1 $1^{+}$gene, encodes a subunit of the Cdc28 protein kinase complex. Mol Cell Biol 9: 2034-2041, 1989. 
8. Richardson HE, Stueland CS, Thomas J, Russell P and Reed SI: Human cDNAs encoding homologs of the small p34Cdc28/ Cdc2-associated protein of Saccharomyces cerevisiae and Schizosaccharomyces pombe. Genes Dev 4: 1332-1344, 1990.

9. Ganoth D, Bornstein G, Ko TK, et al: The cell-cycle regulatory protein $\mathrm{Cks} 1$ is required for $\mathrm{SCF}(\mathrm{Skp} 2)$-mediated ubiquitinylation of p27. Nat Cell Biol 3: 321-324, 2001.

10. Spruck CH, de Miguel MP, Smith AP, et al: Requirement of Cks2 for the first metaphase/anaphase transition of mammalian meiosis. Science 300: 647-650, 2003.

11. Egan EA and Solomon MJ: Cyclin-stimulated binding of Cks proteins to cyclin-dependent kinases. Mol Cell Biol 18: 3659-3667, 1998.

12. Jemal A, Siegel R, Ward E, et al: Cancer statistics, 2008. CA Cancer J Clin 58: 71-96, 2008.

13. Lambert R, Guilloux A, Oshima A, et al: Incidence and mortality from stomach cancer in Japan, Slovenia and the USA Int J Cancer 97: 811-818, 2002.

14. Parkin DM, Bray F, Ferlay $\mathrm{J}$ and Pisani P: Global cancer statistics, 2002. CA Cancer J Clin 55: 74-108, 2005.

15. Tominaga S: Decreasing trend of stomach cancer in Japan. Jpn J Cancer Res 78: 1-10, 1987.

16. Sugiyama T, Hige S and Asaka M: Development of an H. pyloriinfected animal model and gastric cancer: recent progress and issues. J Gastroenterol 37 (Suppl 13): 6-9, 2002.

17. Uemura N, Okamoto S, Yamamoto S, et al: Helicobacter pylori infection and the development of gastric cancer. N Engl J Med 345: 784-789, 2001.

18. Yasui W, Oue N, Kuniyasu H, Ito R, Tahara E and Yokozaki H: Molecular diagnosis of gastric cancer: present and future. Gastric Cancer 4: 113-121, 2001

19. Masuda TA, Inoue H, Nishida K, et al: Cyclin-dependent kinase 1 gene expression is associated with poor prognosis in gastric carcinoma. Clin Cancer Res 9: 5693-5698, 2003.

20. Japanese Gastric Cancer Association: Japanese Classification of Gastric Carcinoma - 2nd English Edition. Gastric Cancer 1: 10-24, 1998.

21. Mimori K, Mori M, Shiraishi T, et al: Clinical significance of tissue inhibitor of metalloproteinase expression in gastric carcinoma. Br J Cancer 76: 531-536, 1997.
22. Ogawa K, Utsunomiya T, Mimori K, et al: Clinical significance of elongation factor-1 delta mRNA expression in oesophageal carcinoma. Br J Cancer 91: 282-286, 2004.

23. Li M, Lin YM, Hasegawa S, et al: Genes associated with liver metastasis of colon cancer, identified by genome-wide cDNA microarray. Int J Oncol 24: 305-312, 2004.

24. De Wit NJ, Rijntjes J, Diepstra JH, et al: Analysis of differential gene expression in human melanocytic tumour lesions by custom made oligonucleotide arrays. Br J Cancer 92: 2249-2261, 2005.

25. Scrideli CA, Carlotti CG Jr, Okamoto OK, et al: Gene expression profile analysis of primary glioblastomas and non-neoplastic brain tissue: identification of potential target genes by oligonucleotide microarray and real-time quantitative PCR. J Neurooncol 88 281-291, 2008

26. Rickman DS, Bobek MP, Misek DE, et al: Distinctive molecular profiles of high-grade and low-grade gliomas based on oligonucleotide microarray analysis. Cancer Res 61: 6885-6891, 2001.

27. Kawakami K, Enokida H, Tachiwada T, et al: Identification of differentially expressed genes in human bladder cancer through genome-wide gene expression profiling. Oncol Rep 16: 521-531, 2006.

28. Kang MA, Kim JT, Kim JH, et al: Upregulation of the cycline kinase subunit CKS2 increases cell proliferation rate in gastric cancer. J Cancer Res Clin Oncol 135: 761-769, 2009.

29. Lan Y, Zhang Y, Wang J, Lin C, Ittmann MM and Wang F: Aberrant expression of $\mathrm{Cks} 1$ and $\mathrm{Cks} 2$ contributes to prostate tumorigenesis by promoting proliferation and inhibiting programmed cell death. Int J Cancer 123: 543-551, 2008.

30. Urbanowicz-Kachnowicz I, Baghdassarian N, Nakache C, et al: ckshs expression is linked to cell proliferation in normal and malignant human lymphoid cells. Int J Cancer 82: 98-104, 1999.

31. Wiese AH, Auer J, Lassmann S, et al: Identification of gene signatures for invasive colorectal tumor cells. Cancer Detect Prev 31: 282-295, 2007.

32. Uchikado Y, Inoue $\mathrm{H}$, Haraguchi $\mathrm{N}$, et al: Gene expression profiling of lymph node metastasis by oligomicroarray analysis using laser microdissection in esophageal squamous cell carcinoma. Int J Oncol 29: 1337-1347, 2006. 